\title{
Residential Mobility and Post-Move Community Satisfaction: Empirical Evidence from Guangzhou, China
}

\author{
Sanqin Mao ${ }^{1}$ and Jie Chen ${ }^{1,2, *(1)}$ \\ 1 School of International and Public Affairs, Shanghai Jiaotong University, Shanghai 200240, China; \\ alicemao01@sjtu.edu.cn \\ 2 China Institute of Urban Governance, Shanghai Jiaotong University, Shanghai 200240, China \\ * Correspondence: chenjie100@sjtu.edu.cn
}

Citation: Mao, S.; Chen, J.

Residential Mobility and Post-Move Community Satisfaction: Empirical Evidence from Guangzhou, China. Land 2021, 10, 741. https://doi.org/ 10.3390/land10070741

Academic Editor: Thomas Maloutas

Received: 17 June 2021

Accepted: 13 July 2021

Published: 15 July 2021

Publisher's Note: MDPI stays neutral with regard to jurisdictional claims in published maps and institutional affiliations.

Copyright: (c) 2021 by the authors. Licensee MDPI, Basel, Switzerland This article is an open access article distributed under the terms and conditions of the Creative Commons Attribution (CC BY) license (https:/ / creativecommons.org/licenses/by/ $4.0 /)$.

\begin{abstract}
In the last few decades, urban communities in China have experienced unprecedented social and spatial changes under the heightened mobility, which is induced by urban redevelopment and expansion. Prior works of community satisfaction of Chinese urban residents gave little attention to the influence of past residential mobility experiences, which is insufficient to capture the dynamics of urban community in a rapidly changing environment. The paper attempts to address this deficiency in the literature by including characteristics of a resident's last mobility experience in the model to understand the resident's community satisfaction based on a city-wide survey in Guangzhou, China. The two-level linear hierarchical regression analysis substantiates the importance of the last mobility experience in a resident's satisfaction with current community. It reveals that those experienced the "upgrade" relocation from informal communities to formal communities, or former work unit compounds to developed commodity housing estates, will be more satisfied with the community than those did not have such experience. It also reveals that the effects of a resident's personal and socio-economic characteristics on the resident's community satisfaction also heavily depend on his or her most recent mobility pattern. The findings in this paper have both policy and practical implications for informing community governance and urban planning in China and worldwide.
\end{abstract}

Keywords: residential mobility; community satisfaction; Guangzhou; urban China

\section{Introduction}

The thirty plus years of economic and housing reforms in the past decades have brought radical changes in households' residential behaviors in urban China [1-3]. In comparison with the pre-reform era when the residence was determined by the state work unit (danwei in Chinese) and residential mobility (or intra-urban migration) was rigorously circumscribed, the rate of residential mobility increased moderately since the end of the 20th century and reached above 10 percent in the beginning of twenty-first century in large cities like Beijing and Guangzhou [4-6]. Such heightened mobility has brought drastic transformation to the communities in urban China at an unprecedented scale. How to build up a place-based emotional connection with the community after households experienced residential relocation has been an acute social challenge, as the community accommodates a mix of residents which is still increasing and is the basis for social cohesion and urbanites' well-being. The literature has pointed out that the responses to the community environment after experiencing a residential mobility event has major implications for this individual's quality of life as well as for community construction [6,7]. In view of the scale and pace of the community transformation and heightened residential moves in recent decades, extant studies have tried to explore subject feelings of residents towards communities after they experienced relocation [8,9]. For example, Li and Song [10], using survey data collected in Shanghai, find that higher degree of satisfaction towards communities will be among those displaced residents when their housing conditions are better off during the forced relocation. Song et al. [11] reach a similar result and highlight that many displaced 
residents are strongly connected with their living environment. However, Zhang and $\mathrm{Lu}$ [12] argue that improved residential environment does not necessarily contribute to increased satisfaction. Through their interviews in two communities in Beijing, they found that residents living in redeveloped communities were more likely to report lower levels of satisfaction than those in communities without redevelopment, even though the residential conditions, neighborhood built environment, and facilities have progressed greatly due to the regeneration program. Much attention has been paid to migrants who experienced substantially high residential instability than local residents [13-15].

Invariably, the extant studies mainly focus on migrants and displaced residents. To date, there is scant research incorporating the movement background into the community satisfaction discourse in Chinese cities, despite it being well known that residential mobility is intimately related to the degree of community satisfaction through changes in lifestyles, environmental factors, local social capital, accessibility to employment, and urban resources of various kinds [6]. Among the few exceptions are as follows: $\mathrm{Wu}$ [8] found that relocated residents in Shanghai are generally more satisfied with their residence by changes in housing tenure and conditions, and voluntary movers are in a better position than involuntary movers; Wang and Wang [16] similarly report incremental residential satisfaction among movers in Beijing mainly owing to improvements in housing conditions and neighborhood environment. Much more consideration should be given to the association between residential mobility and community satisfaction and at least two research gaps need to be filled concerning previous studies. The first is that little is known about how community satisfaction varies across households with different mobility experiences. The second research gap is answering how the correlation between individual characteristics and community satisfaction is conditioned upon mobility experiences, which is a topic that has rarely been discussed in previous studies. This paper aims to fill the above two research gaps by generating an empirical understanding of the relationship between satisfaction and mobility in the Chinese urban using a city-wide survey conducted in Guangzhou. Such an analysis would offer new knowledge to assist policy-makers and practitioners to effectively create a cohesive and inclusive community that tailored to the characteristics and needs of residents. This study can also help to enlighten policies and practices related to community governance in China and wider regions.

In the following part, we first review the theory of community satisfaction and its predictors and formulate several hypotheses. Next, we describe the suitable methods and data in the paper. We then try to analyze the extent to which the mobility experience affects the post-move community satisfaction in a multi-level linear hierarchical regression framework. At last, implications and avenues for future study are given.

\section{Literature Review and Hypothesis Development}

\subsection{Research Regarding Community Satisfaction}

Community satisfaction, which reflects the gap between residents' actual and aspired community situations, can offer a revealing insight into the nature of social life in communities $[17,18]$. As an important indicator of residents' perceptions of quality of their current residential environment, it has major implications for residents' well-being, for community sustainability and change, and for local community governance [18,19]. Therefore, community satisfaction and the reasons for it have captured the attention of generations of scholars. As community satisfaction is influenced by numerous environmental and socioeconomic and demographic attributes, including public and private amenities and access to basic facilities, factors related to the degree of satisfaction are complicated. To date, there have been many papers that have attempted to examine more of the complex construct. The extant works on reasons for community satisfaction can be classified according to the influence factors, for example, by the built environment [20] and the institutional, cultural, and social-economic context in which satisfaction is formed [21-23]. The literature can also be classified by the heterogeneity across population groups of different demographic and socio-economic characteristics such as the youth, the middle-aged, the elderly, the low income, 
and rural migrants $[8,15,24,25]$. Those studies help shed light on how community-level and individual-level variables are associated with the degree of community satisfaction.

Evidently, incorporating elements of mobility experiences, which is supposed to bring about a set of changes including improved living conditions and environment and new social connections, within the variables of community satisfaction enriches the research. Based on theories of residential selection and mobility, the residential move is a spatial process which is made to promote residential circumstances to acceptable levels of housing and community satisfaction [26-28]. Despite the fact that the residential move only happened in a short period of time, the move event can have a sustained effect on residents' attitudes, health, and well-being [29]. Nonetheless, the actual outcome of the residential move depends on the interaction between residents' motives, resources, and restrictions, on the one hand, and the opportunities and constraints in specific social contexts, on the other [30]. Thus, residents with dissimilar personal experiences under diverse social-economic and institutional contexts would have vastly distinct housing and neighborhood experiences $[5,16,27]$.

In general, mobility experiences as captured by three aspects (motivations for moving, the spatial distance of the move, and history of migration) play a key role in last outcome of residential mobility and influence individuals' subjective feelings toward the new community [31]. First, as for motivations for moving, people who engaged in voluntary moves are more prone to exhibit greater satisfaction with the new community than those who encounter involuntary relocation [31]. For instance, Temelová and Slezáková [32] analyzed the correlation of residents' experience of community change and satisfaction using their in-depth interviews in three Prague's housing estates and revealed that residents who move involuntarily tend to engage in stricter comparison between their new homes with previous ones, and their acceptance of current residence is generally lower. Second, as for the spatial distance, it has also been found that spatial distance of residential move is directly related to the knowledge of the new environment, which obviously affects how well the resident adjusts to the present neighborhood, thus shaping the resident's attitudes towards the new neighborhood [7]. What is more, the community of origin and the destination influence the level of satisfaction with the community. Brazil [33] reveals that Hispanics exhibit a stronger degree of neighborhood satisfaction in new destinations in contrast with Hispanics residing in established destinations, by examining the satisfaction levels and determinants of Hispanics in USA.

Works on processes of heightened residential movement and post-move community satisfaction are of notable significance in China, where the unprecedented spatial and social transformation and restructuring of urban communities are emerging in many cities [34]. The decades of political and economic reforms, including work unit and housing reform within China, have brought phenomenal changes in residential mobility and thereby creating new neighborhood environment in recent decades $[13,35]$. In the pre-reform period, residential mobility was limited in cities in consequence of the welfare allocation system and approximately lifetime recruitment [1]. The residential compounds were built and distributed by the socialist work unit (danwei). The housing reform and work unit reform begun in the 1980s led to the emergence of a more mobile and economically independent urban population. The demolition of former socialist communities (workunit/reform housing compounds) and the spreading of massive contemporary commodity housing projects (developed commodity housing estates) have produced privatization and commercialization of community space. The cessation of the welfare housing allocation in 1998 totally implicated that to Chinese citizens housing has changed to a consumption item [25]. Commodity housing estates have quickly replaced former neighborhoods.

Responding to the growth of intra- and within-urban mobility and community transformation in China, there have been increasing works examining neighborly relations and satisfaction after relocation. Surveys reveal that personal socio-demographics such as age, gender, homeownership, duration of residence, and community characteristics such as built environment are associated with community satisfaction e.g., [13,36]. 


\subsection{Hypothesis Development}

In addition to the factors of personal socio-demographics and community characteristics that having been studied in previous literature, our study supposes that important aspects of residential mobility are also related to post-move community satisfaction. In this study, we try to explore whether and how elements of mobility experiences are associated with community satisfaction and if there are interactions of individuals' socio-economic characterizes with elements of mobility experiences in predicting community satisfaction. To be specific, we propose three hypotheses regarding the relationship between last mobility experience and satisfaction with current community.

First, we propose the movers who experienced different changes of community quality would have different degrees of satisfaction with the current community. In urban China, there are four distinct types of residential communities: commodity housing community, work-unit yard, privatized public housing community, and urban villages or self-built settlements [37]. The quality of a residential community can be assessed from three perspectives: dwelling quality, community amenity (public facilities, parking, and greenness, etc.), and services delivery, where the last one includes whether there is gated security protection, garbage collection, sufficient property maintenance, organized community activities, etc. In any perspective of community quality, commodity housing communities are undoubtedly ranked at the top, where work-unit yard and privatized public housing communities are in the middle, while urban villages and self-built settlements are deemed lowest. Thus, in this paper, we define a move from any other type of community to commodity housing community as a "upgrade move" or climbing up on the community ladder, a move from commodity housing community to any other community as a "downgrade move" or a lower-down on the community ladder, and a move within the same or similar community as a "level move" or staying on the community ladder. Note that a change in community type usually indicates not only significant change in the dwelling conditions and community amenity but also drastic disruption of social networks. For example, several earlier studies show that during the shift from former work-unit yard to new commodity housing communities, acquaintances, interactions and mutual trust among remaining residents are declined in general, which is in line with the argument of "community lost" [34,38]. Nonetheless, despite weaker local networks in commodity housing communities, there have generally higher community satisfaction resulting from the improved physical environment for these residents $[9,10]$. We thus expect similar effects would occur among all residents experienced a "upgrade" of community. Therefore, we propose the first hypothesis of this paper as following:

Hypothesis 1. Community satisfaction would be higher among those movers who experienced "upgrades" of community quality but lower among those movers who experienced "downgrades" of community quality, holding other equal.

However, it is reasonable to expect different aged groups may have different benefits and costs from moving into communities that different from previous ones. Studies have showed that the elderly in redeveloped communities express lower overall levels of satisfaction even when the communities have better access to public utilities and improved physical infrastructure of dwelling units [12]. This is, on one hand, because the elderly care more about involvement in community activities and developed social networks in original communities, on the other hand because, compared to young adults, the elderly who experience severe shortages have lower expectation with dwelling quality and less utilization demand of community amenity [5]. Residential mobility is likely to bring them fundamental changes in daily routines and severe loss of long-established social ties [8]. Thus, we derive the second hypothesis of this paper as follows.

Hypothesis 2. The relationship between community satisfaction and change of community quality would be different across different age groups. 
Meanwhile, we suspect that those that have experienced different spatial relocation would have different satisfaction for the current community. Spatial change of residential mobility is associated with major changes in family life, community profiles, and spatial relations of various kinds, and thereby affect satisfaction with the new environment [8]. In view of the suburbanization process in China, more attention has focus on residents migrated from the inner cities to the suburbs. As Chinese cities are mostly monocentric and urban amenity, in terms of job opportunities, variety of cultural and entertainment options, and accessibility to good schools, parks, museums, hospitals, etc. are generally much better in the city centers than in the suburban areas $[39,40]$. Studies of the relocated residents generally report a lower level of satisfaction with the current environment, because of the inadequate access to hospitals grocery stores and post offices [41]. Not considering those inadequate access, people are not too dissatisfied with the new dwellings and not difficult to adapt to the new environment, because of the improved living conditions and hope to see their current residential place to new urban centers $[10,11]$. As for the inadequate access, studies argue that the lower-income groups are more affected in relation to accessibility losses and housing costs, compared to higher-income residents [41]. Note that the new urban middle class, usually young educated, have play a pivotal role in the suburban gated housing estates [5,42]. They are aspiring a new lifestyle, have developed specific ideas about their living environment and use online-offline community forum to participate community affairs and governance [42]. Despite the outward process, a substantial proportion of the middle class and elites are tried to settle and resettle in the city center, where have the top education as well as infrastructure supports $[5,43]$. Then, the third hypothesis of this paper is suggested as following:

Hypothesis 3. Community satisfaction will be generally higher when the movers experienced inward mobility, but such correlation is also dependent on the mover's socio-economic characterizes.

This study will build on existing works to illustrate how a concrete measure of mobility experiences might influence post-move community satisfaction. Besides, residential communities have experienced changes both in the built environment and the demographics. Attempts will also be made to reveal how residents confront with the dynamic community under the community-transformed perspective.

\section{Data and Research Method}

\subsection{Data Collection}

The data employed by this study came from the city-wide household survey completed in early 2013 in the City of Guangzhou, which witnesses the most dramatic changes amongst southern cities and is thus an impressive place to be selected to understand urban citizens' attitudes toward their current residence. The survey is led by the combination of Duke University, Hong Kong Baptist University, and Sun Yat-sen University. A great deal of information about respondents' retrospective migration trajectories and perception of community's physical and social environment are solicited from the survey. We employed the multi-stage probability proportionate to size sampling (PPS) process to maximize the representativeness of the sample.

First, the total 139 streets (jiedao) within the geographical boundaries of Guangzhou city were categorized into three distance zones (or primary sampling unit strata): the inner core area (52), the inner suburb (45), and the outer suburb area (42). The demarcation line of distance zones was determined based on historical division, population density, and land use processes. Streets in county-level cities like Nansha and Zengcheng were excluded. Second, according to population size of each street and the total number of streets, 30 streets or sub-districts (12 in the inner core, 11 in the inner suburbs, and 7 in the outer suburbs) were randomly selected by a GIS sampling method. Third, 2-3 urban communities (xiaoqus) in each street were randomly chosen and a list of surrounding communities was also prepared (the exact number depending on the sizes of these communities). Last, within 
each chosen community, respondents were selected via an interval sampling method according to populations size of the community and house number. If a target participant rejects the face-to-face interview, the resident next door would be invited.

In total, 39 communities that vary in sizes, types and locations within the city were chosen (see Figure 1). A total of 1662 valid questionnaires were collected.

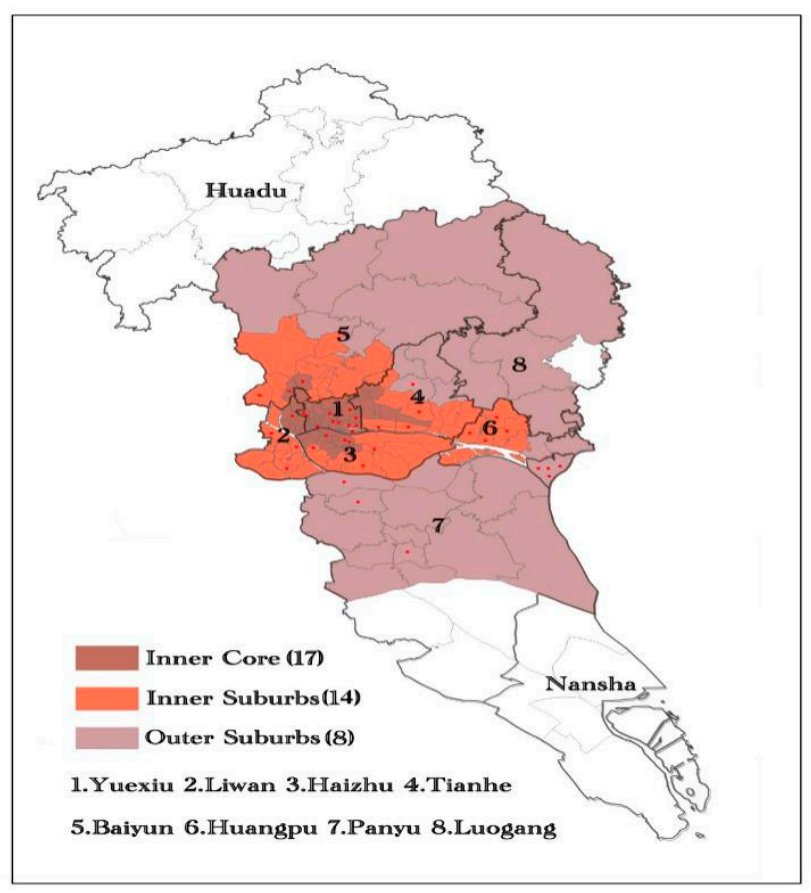

Figure 1. Distribution of surveyed communities.

By design, the survey covered a wide range of residential blocks such as newly commodity housing communities, old work-unit/reform housing compounds, as well as old, dilapidated neighborhoods located in inner core area. Only informal housing like urban villages and self-built settlements where low-income migrants and other disadvantaged people live were not included. Therefore, the sample size of migrant workers may be inadequate. It is worthwhile to research this segment of the urban population specifically in future studies. Nonetheless, along with the further market-oriented reform, the filtering process has turned into an essential component of urban transformation and housing development. In recent years, formal housing, like work-unit/reform housing compounds, has seen substantial inhabitation by migrant workers [5,6]; it is also evidenced by comparison with the 2010 Population Census of Guangzhou City. The percentage of migrants given by the sample is $28.52 \%$, whereas the percentage given by the entire population is $36.32 \%$. Moreover, regarding age, people aged $21-64$ constitute $86.28 \%$ of the sample and $81.91 \%$ of the population census. Regarding gender, males make up $43.80 \%$ of the sample and $52.26 \%$ of the population census. Therefore, the comparison indicates little difference between the sample and population census distributions.

\subsection{Measures of Community Satisfaction and Independent Variables}

Table 1 lists the statistics of the dependent and independent variables. The dependent variable in the study is community satisfaction, and it is measured following a previous study's method [44]. The respondents were asked to evaluate their living environment by responses to the statement, "I like the neighborhood as a living place" on a five-point scale from "strongly disagree" to "strongly agree". On the whole, respondents are almost satisfied with their living place, giving them an average score of 3.75, which was just less than "agree". 
Table 1. Descriptive analysis of dependent and independent variables $(n=1662)$.

\begin{tabular}{|c|c|c|c|}
\hline Variables & Classification & Obs. & Mean/\% \\
\hline Community satisfaction & & 1662 & 3.75 \\
\hline \multicolumn{4}{|l|}{ Personal level } \\
\hline Age & Years of age (Years) & 1662 & 44.76 \\
\hline \multirow[t]{2}{*}{ Gender } & Male & 728 & 43.80 \\
\hline & Female & 934 & 56.20 \\
\hline \multirow[t]{2}{*}{ Hukou } & Local & 1188 & 71.48 \\
\hline & Non-local & 474 & 28.52 \\
\hline Income & Family income (ten thousand Yuan) & 1662 & 14.36 \\
\hline Education & Years of schooling (Years) & 1662 & 12.04 \\
\hline \multirow[t]{2}{*}{ Child in house } & Yes & 920 & 55.35 \\
\hline & No & 742 & 44.65 \\
\hline \multirow{2}{*}{ Tenure } & Yes & 1329 & 79.96 \\
\hline & No & 333 & 20.04 \\
\hline \multirow{4}{*}{ Job rank } & Clerical/technical worker & 228 & 13.72 \\
\hline & Manual/services worker & 239 & 14.38 \\
\hline & others & 835 & 50.24 \\
\hline & Administration/professional & 359 & 21.60 \\
\hline Length of residence & Years of residence (Years) & 1662 & 7.19 \\
\hline \multirow[t]{3}{*}{ Mobility pattern } & $\begin{array}{l}\text { U1: Urban village, self-settlement, privatized public } \\
\text { housing-commodity housing }\end{array}$ & 303 & 18.23 \\
\hline & U2: Work-unit/reform housing-Commodity housing & 442 & 26.59 \\
\hline & L or D: Commodity housing-Commodity housing and others & 917 & 55.18 \\
\hline \multirow{3}{*}{ Migration direction } & Inward move (Suburbs-inner city) & 175 & 10.66 \\
\hline & Outward move (Inner city-suburbs) & 294 & 17.90 \\
\hline & Within-zone move & 1173 & 71.44 \\
\hline Community level & & & \\
\hline Built environment & & & 3.51 \\
\hline \multirow{2}{*}{ Community composition } & Percentage of homeowners & & 0.81 \\
\hline & Percentage of migrants & & 0.35 \\
\hline Community stability & Percentage of people having lived here pass five years & & 0.62 \\
\hline Community scale & Population size of the community & & 1967 \\
\hline
\end{tabular}

The set of independent variables consists of two levels. The first level includes sociodemographic characteristics and elements of mobility experience. As control variables, the former refers to age, gender, hukou status, presence of children, years of schooling, occupation rank, and home ownership. As shown in Table 1, the average age of the sample is $\sim 45$ years old. Eight-hundred-and-four are male of the total sample. The majority of respondents have Guangzhou Hukou (1188 residents, 71.48\%). Concerning years of schooling, $902(50.99 \%)$ participants stated that they had completed their further study after high school, reflecting the tremendous expansion of college enrolment in the late 1990s. With respect to family construction, 55 percent of the sample have child in house. As for tenure status, the rate of homeownership tops 79 percent in 2013, a rate that is higher than many developed countries [2]. In terms of occupation status, $1097(61.52 \%)$ were employed and 686 (38.47\%) were retired. The socio-demographic attributes in this study are consistent with the set of control variables employed in extant satisfaction works [7,20].

The mobility experience variables will be derived from retrospective residential histories elicited through the survey. Among the mobility experience measures are:

i. Mobility pattern, i.e., change in housing type. According to the sorting scheme in the literature review, three mobility patterns can be identified: 1 . from urban village, public housing and self-settlement to commodity housing community (Upgrade 1), $18.23 \%$; 2 . from work-unit/privatized public housing community to community housing community (Upgrade 2), 26.59\%; 3. moved between same or similar type of community or from higher-standard community to lower-standard community (Level or Downgrade), $55.18 \%$. Because in the total sample, respondents rarely experience the downgrade move (only $0.48 \%$ ), we merge the level move and the downgrade move into one type.

ii. Migration direction. It is also represented by three categories, that is inward moves $(10.66 \%)$, outward moves $(17.90 \%)$, within-zone moves $(71.44 \%)$. 
iii. The motivation for the move and length of residence. Because of the nature of the survey, motivations of the move are missing. Further studies are needed on this reason in our future research. The average length of residence of the sample is 7.03 years.

The second level refers to the characteristics of the present neighborhood, which reflect aggregated outcomes of individuals' residential moves. They are gauged by, inter alia, community stability, community built environment, community scale, the percentage of homeowners, and non-local hukou residents. The variable "community stability" is measured by the share of households having lived in the community over five years [45]. With respect to the community scale, the average size of total sample is 1003 households. Community built environment is generally identified as key determinant of community satisfaction, which is created using the principal component analysis strategy (see Table 2). The average of participants' responses to five items on a scale of 1 (extremely unsatisfied) to 5 (extremely satisfied) is 3.51 (alpha value $=0.71$ ).

Table 2. Principal components analysis of community environment evaluation.

\begin{tabular}{lccc}
\hline & Percent “Extremely Satisfied” & Mean & Component \\
\cline { 3 - 4 } & & 68.42 & 0.536 \\
\hline (a) Transport convenience & 46.93 & 3.83 & 0.658 \\
(b) Overall architectural design & 52.86 & 3.44 & 0.790 \\
(c) Cleaning & 44.04 & 3.50 & 0.755 \\
(d) Responsiveness of estate management company to & & 3.32 \\
individual requests & 50.06 & 3.43 & 0.783 \\
(e) Maintenance of public facilities in community (like lifts & 54.78 & 3.53 & 0.730 \\
and water pumps) & & \\
(f) Responsible security guards & & & \\
\hline
\end{tabular}

\section{Empirical Analysis and Findings Discussions}

We conduct both conventional OLS model and multi-level model to verify the relationship between residential mobility and community satisfaction. The likelihood ratio test justifies the usage of the multi-level model since it works better than the common OLS model $(p<0.001)$. We also check the multicollinearity of the variables and all values of VIF are lower than 6 which indicates the multicollinearity of the variables do not influence the model outcome. Interaction terms which did not apparently improve the goodness of fit of the model are excluded. The final result of the two-level regression model is showed in Table 3.

\subsection{Level-1 Variables: Socio-Demographic Characteristics and Elements of Mobility Experience}

As for control variables, this finding is in line with existing studies and suggests that homeownership is key differentiator of community satisfaction e.g., [16,36]. The results on aspects of residential mobility confirms that individual mobility experience is significant associated with community satisfaction. It shows residents who have once resided in the former work-unit compounds, and are presently in the newly developed commodity housing estates, are more satisfied with their community, which confirms our first hypothesis. It is understandable that the improvement of housing and community conditions foster greater satisfaction with the community, even though the move is combined with the severance of emotional bonds with acquaintances in the work-unit yard. This confirms with prior research that community satisfaction is probably derived more from community built environment rather than from neighbor connections [9]. Likewise, moving from informal housing, resettled housing or affordable housing to commodity housing communities also report higher level of satisfaction with their new community, which again reinforces the present-day importance of the built environment to community satisfaction. With respect to the interaction terms, the present of children and income interact with change in housing type. First, households with children are more satisfied with their community when moving from reform housing to commodity housing than those without. It is probably 
because the provision of communal space, sanitation, children's playgrounds, and security from the commodity-housing estates do bring families with children a safer and healthier environment and hence increasing community satisfaction. Second, movers with higher income tend to report greater community satisfaction than those with lower income among movers moving out of the reform housing to the commodity housing. This is not surprising as rising income enhance advancements along the housing and neighborhood ladder and hence satisfaction with the neighborhood. It reflects that now income plays primary role in determining which community to live. During the urban social-spatial restructuring process, affluent households have a better chance to acquire aspired community situations through residential moves, whereas the impoverished households are probably driven to poor locations despite improved residential environment.

Table 3. Results of the mixed effect linear hierarchical regression of community satisfaction.

\begin{tabular}{|c|c|c|}
\hline & & Community Satisfaction \\
\hline \multicolumn{3}{|l|}{ Fixed effects } \\
\hline (Constant) & & 3.125 \\
\hline \multicolumn{3}{|l|}{ Level-1 variables } \\
\hline Age & & 0.010 \\
\hline Gender & $1=$ male $; 0=$ female & 0.047 \\
\hline Hukou & $1=$ local $; 0=$ non-local & 0.081 \\
\hline Income & & 0.001 \\
\hline Education & & -0.013 \\
\hline Child in house & $1=$ yes $; 0=$ no & -0.008 \\
\hline Tenure & $1=$ homeowner; $0=$ tenant & $0.061 *$ \\
\hline \multirow[t]{3}{*}{ Occupation (reference $=$ Manual $/$ services worker) } & Clerical/technical worker & -0.005 \\
\hline & Administration/professional & 0.099 \\
\hline & others & 0.090 \\
\hline Length of residence & & 0.012 ** \\
\hline \multirow{2}{*}{$\begin{array}{l}\text { Mobility pattern } \\
\text { (reference = Commodity housing-Commodity housing and others) }\end{array}$} & $\begin{array}{l}\text { U1: Urban village, self-settlement, } \\
\text { etc.-commodity housing }\end{array}$ & $0.036^{*}$ \\
\hline & $\begin{array}{l}\text { U2: Work-unit/reform } \\
\text { housing-Commodity housing }\end{array}$ & $0.317^{* *}$ \\
\hline Migration direction & Inward move & 0.115 \\
\hline (reference = Within-zone move) & Outward move & -0.586 \\
\hline \multicolumn{3}{|l|}{ Level-2 variables } \\
\hline Built environment & & $0.395^{* * *}$ \\
\hline \multirow[t]{2}{*}{ Community composition } & Percentage of homeowners & $0.006^{*}$ \\
\hline & Percentage of migrants & -0.001 \\
\hline Community stability & & 0.072 \\
\hline \multirow{2}{*}{$\begin{array}{l}\text { Community scale } \\
\text { Interaction terms }\end{array}$} & & -0.011 \\
\hline & & \\
\hline \multirow{2}{*}{$\begin{array}{l}\text { Income } \times \text { Mobility pattern } \\
\text { (reference }=\mathrm{L} \text { or D: Commodity housing-Commodity housing and others) }\end{array}$} & $\begin{array}{l}\text { U1: Urban village, self-settlement, } \\
\text { etc.-commodity housing }\end{array}$ & -0.007 \\
\hline & $\begin{array}{l}\text { U2: Work-unit/reform } \\
\text { housing-Commodity housing }\end{array}$ & $0.008 *$ \\
\hline \multirow{2}{*}{$\begin{array}{l}\text { Child in house } \times \text { Mobility pattern } \\
\text { (reference = L or D: Commodity housing-Commodity housing and others) }\end{array}$} & $\begin{array}{l}\text { U1: Urban village, self-settlement, } \\
\text { etc.-commodity housing }\end{array}$ & -0.019 \\
\hline & $\begin{array}{l}\text { U2: Work-unit/reform } \\
\text { housing-Commodity housing }\end{array}$ & $0.142 *$ \\
\hline \multirow{4}{*}{$\begin{array}{l}\text { Age } \times \text { Migration direction } \\
(\text { reference }=\text { Within-zone move) } \\
\text { Income } \times \text { Migration direction } \\
\text { (reference = Within-zone move) }\end{array}$} & Inward move & 0.002 \\
\hline & Outward move & $-0.006^{*}$ \\
\hline & Inward move & $0.016^{* *}$ \\
\hline & Outward move & -0.004 \\
\hline \multirow{2}{*}{$\begin{aligned}(\text { reference }=\text { Within }- \text { zone move }) & \\
& \text { Education } \times \text { Migrat } \\
& \text { (reference }=\text { Within }\end{aligned}$} & Inward move & 0.032 \\
\hline & Outward move & $0.016^{* *}$ \\
\hline Child in house $\times$ Migration direction & Inward move & $0.065 *$ \\
\hline (reference $=$ Within-zone move) & Outward move & $-0.156 *$ \\
\hline \multicolumn{2}{|l|}{ Age $\times$ Community stability } & $0.001^{* * *}$ \\
\hline \multirow{2}{*}{\multicolumn{2}{|c|}{$\begin{array}{l}\text { Random effects } \\
\operatorname{Var} \text { ( cons) }\end{array}$}} & \\
\hline & & 0.020 \\
\hline \multicolumn{2}{|l|}{ Var(residual) } & 0.612 \\
\hline \multicolumn{2}{|l|}{ Model fix statistics } & \\
\hline 2 Log Likelihood & & 3620 \\
\hline
\end{tabular}


As for the migration direction, the parameter estimate is not significant. However, confirming the third hypothesis, the respondent's age, education, income, and household structure interact with location change, which suggests the correlation between community satisfaction and spatial flow, depend on movers' demographic and socio-economic characteristics. First, younger and better educated movers are more satisfied with their new community after outward move. As mentioned in prior studies, recent years the well-equipped apartments in the ever-expanding suburbs not only offer an opportunity for young people to enter the housing market, but also have attracted many professionals to move in to pursue of a new living ideal $[42,46]$. Those young professionals are more satisfied with their new living environment and willing to join force with their neighbors in community governance to cultivate community spirit and passionately combine with them to undertake their shared disputes and problems [42]. Compared with young adults, residential relocation could be disturbing for senior citizens like elderlies elsewhere in the world, which cause changes in daily situation [5]. Most importantly, moving to distant suburbs is prone to reduce contact with their long-established social ties because of their travel and e-communication inconvenience.

Second, better-off movers report higher community satisfaction after inward move. Undoubtedly, after large-scale gentrification and redevelopment, the midst of the city is still the place that best living conditions with better access to various resources are found despite the increasing suburbanization process. As the housing price in the heart of the city has been rising to extreme highs, the low-income households suffer more locational restriction and only better-off residents can afford to move to a community with better spatial resources in the city center. These differentiated mobility flows based on income lead to clear clustering patterns and exacerbate residential segregation, a problem common in many Western cities [28]. However, not analogous to the Western experience, the city center is still a place for the rich. Last, the association between presence of children and community satisfaction depends on mobility patterns. Specifically, presence of children is positively associated with community satisfaction among inward movers, while it is negatively related to community satisfaction among outward movers. This is understandable considering the superior educational resources and public facilities remain concentrated in the city center $[39,40]$. Families with children are usually more satisfied with their neighborhood environment when involving in inward move. By contrast, the suburban areas fall behind in many aspects of a learning and supporting environment such as education resources and supporting facilities. Of those moving outwards into the outer suburban areas, parents with children are therefore more dissatisfied with their environment than those without. The interaction among children's education, residential mobility and community satisfaction reflects detail process about the outstanding capitalization effect of school quality (xuequfang in Chinese).

\subsection{Level-2 Variables: Characteristics of the Present Neighborhood (Reflection of Aggregated Outcomes of Individuals' Residential Moves)}

Surely, in line with the findings of present literature $[9,22,34]$, community built environment is found to have the strongest positive effect on the satisfaction with the community. The better community environment, including landscaping, security, cleanliness, and recreation facilities provision allows for both feelings of comfort and convenience, and thus generates a major source of satisfaction with the residential context. Community stability does not exert significant effect on satisfaction with the community. Community composition does affect the attitude toward the community. People who reported living in the higher share of homeowners in the community are more likely to report higher community satisfaction than those in the lower share of homeowners in the community. Possible reasons for this positive relationship are that the higher share of homeowners surely lead to higher participation in community affairs to pursue a better residential environment [36]. Thus, communities with a higher homeownership rate are inclined to generate higher participation, more frequent local interactions, and thus shape stronger emotional sentiment. The share of migrants in the community, however, is not significant, 
illustrating that citizens are actually indifferent as to whether the community is formed by local or non-local households.

The cross-level interaction shows that older people report higher community satisfaction level in stable communities. Senior citizens tend to be spent more time at home and community. Thus, they tend to have more friends and acquaintances in the community where stable communities have a higher percentage of long-term and elderly people, which may lead to positive feelings and greater satisfaction with the community.

\section{Conclusions}

Wholesale redevelopment, rapid urban growth, and population reshuffling since the mid-1990s have given rise to phenomenal social and spatial restructuring and diversity of urban communities in urban landscape in China. However, despite many elaborations on unprecedented urban spatial transformations, attitudes toward the community underlying the residential mobility are largely ignored. Few have questioned whether and how massive redevelopments and change in population mix are associated with community satisfaction among various socio-demographics. To fill this gap, in this study, we examine the association between residential mobility and post-move community satisfaction. We consider important aspects of mobility experiences and community environment and composition as variables related to community satisfaction. Variables found to be associated with community satisfaction include length of residence, change in housing type, community demographic composition, and community's built environment.

The results suggest that the level of community satisfaction is significantly linked to individuals' mobility experience. To begin with, not surprisingly, those that experienced "upgrades" of communities will be more satisfied with the community than those did not have such an experience. Even though residents living in the new commodity communities experience weaker local interactions and relationships than the old work-unit compounds or informal housing districts, the improved community physical environment and services from neighborhood institutions increase stronger satisfaction [9,47]. Among those moving from the reform housing to commodity housing, families with children are understandably more satisfied with the community with improved environmental quality and public facilities than those without. In addition, as the meaning of housing has changed to a consumption item, individual wealth has been a key determinant of finding better communities $[35,48]$.

Besides, variables like age, income, and education attainment tend to have varying effects on community satisfaction across different spatial patterns of residential mobility. For one thing, the relationship between community satisfaction and migration direction is different across different age groups. Large-scale newly built housing estates in the suburbs offer chances for young professionals to buy a house and climb the housing ladder. For them, the feeling of accomplishment from the mobility fosters their satisfaction toward the new environment. Thus, they are willing to establish ties with neighbors and actively joining forces with new neighbors to solve shared problems [42]. For another, the relationship between community satisfaction and migration direction is also dependent on the mover's family structure and income. Premier education resources (like key schools and training institutions), hospitals, and other infrastructural facilities are still concentrated in the city core [49]. Therefore, families with children are less satisfied with the new environment when it involves an outward move than those without but are more satisfied with inward moves. In addition, the extremely high housing price make individual income an important factor related to community satisfaction among those relocating from the suburbs to the city center. Note that the role of institutional forces, like hukou and work unit, begins to be insignificant comparing with the increasing weight of income in residential choices. Affluent households but not households with local hukou are more likely to acquire better community situations through residential moves.

Moreover, in the past decades, heightened mobility brings communities with different mix of residents. The built environment develops into a progressively significant variable 
than neighbor relations and local networks in making their community satisfied. Services from grassroots state organs like residents' committees (juweihui in Chinese) and street offices, and institutions like estate management firms and homeowners' associations (HOA) are quickly replacing reciprocal help and personal interactions [50]. Therefore, providing better community built environment is a more direct and efficient way to boost community satisfaction especially for old communities. As for the population composition of the community, only percentage of homeowners is associated with community satisfaction. There is no evidence that other components of population composition like migrants' share of the population are related to community satisfaction. The community size also has an ambiguous effect on the community satisfaction.

Overall, community satisfaction can be understood better taking into consideration the residential mobility factors. Unpacking measures of the mobility experience would make a theoretical contribution to a more in-depth understanding of the effect of residential changes on community development and yield meaningful information for understanding cohort effects, residential segregation, and urban restructuring, which have major implications for community organizations to enhance community development and inform community governance, and for urban policymakers to rethink their intensifying inner-core gentrification, suburban resettlement, and other similar ongoing projects. More concretely, our findings have enlightened city builder the following main recommendations. First, cohorts of population have different requirements for social and physical environment after residential changes. For example, while youngsters have a higher expectation with residential quality, the elderly need more social support from neighborhood interactions, especially those relocated from inner areas to the inconvenient suburbs. Therefore, to improve urban citizens' community satisfaction, community planners should consider differentiate environment designs according to demographics compositions of the targeted community. Second, the unbalance of educational resources gives rise to education-induced mobility, which exhibits clear residential segregation. The rich can obtain better education through moving to key school districts houses (zhongdian xuequ fang), which usually located in inner core of the city, and thus maintaining their social status [51]. The combination of education and housing induces severe problems like residential segregation and social polarization. To reduce such spatial segregation and polarization, policy-makers need to realize education balance is the best way to achieve residential integration. Last but not least, there is still a huge gap between the inner core and suburbs in the city, which induce households of different socioeconomic background to exhibit different degrees of community satisfaction when involved in inward or outward mobility. City planners should pay more attention to the living environment of suburbs such as schooling arrangements, public transportation to respond to the redistributing population, especially the aged or disadvantaged groups, from the inner core of the city to the suburban area. Note that the findings of this study are based on data collected from October 2012 to January 2013, which is a bit dated. In recent years, the decreasing number of relocation and demolition projects, the suburban development, and the increased labor mobility may have affected the correlation between residential mobility and the satisfaction toward the neighborhood. Thus, the association of factors like housing tenure shift and move direction with community satisfaction probably changes. However, the research offers a comprehensive and potentially framework for future studies on outcomes of residential mobility in China. In addition, two obvious limitations to this study should be acknowledged. First, due to the lack of motivation factors underlying residential decision and migration history factors like time spent on moving and distance of move, we cannot fully address the mechanisms how mobility reasons affect the settled community satisfaction, which will be our future direction. Second, apart from the main kinds of communities considered in the present studies, informal housing estates should be included in future studies. 
Author Contributions: Conceptualization, S.M.; methodology, S.M.; software, S.M.; validation, S.M.; formal analysis, S.M.; investigation, S.M.; resources, S.M.; data curation, S.M.; writing-original draft preparation, S.M.; writing-review and editing, J.C.; supervision, J.C.; project administration, J.C.; funding acquisition, J.C. All authors have read and agreed to the published version of the manuscript.

Funding: This research was funded by National Natural Science Foundation of China, grant number NSFC71974125: NSF71573166.

Institutional Review Board Statement: Not applicable.

Informed Consent Statement: Not applicable.

Data Availability Statement: Data that support the findings of this study are available from the Corresponding author upon reasonable request.

Acknowledgments: This work is supported by National Funds by FCT-Portuguese Foundation for Science and Technology, under the project UIDB/04033/2020 and ADB grant PQ 303903/2019-8).

Conflicts of Interest: The authors declare no conflict of interest.

\section{References}

1. Huang, Y.; Deng, F.F. Residential mobility in Chinese cities: A longitudinal analysis. Hous. Stud. 2006, 21, 625-652. [CrossRef]

2. Huang, Y.; Yi, D.; Clark, W.A.V. Multiple Home Ownership in Chinese Cities: An Institutional and Cultural Perspective. Cities 2020, 97, 102518. [CrossRef]

3. Chen, J.; Hu, M.; Lin, Z. China's Housing Reform and Labor Market Participation. J. Real Estate Financ. Econ. 2021. [CrossRef]

4. Liu, W.B.; Chen, Z.N.; Yan, X.P. Comparisons of Related Characteristics for Residential Mobility in Different Phases in Transitional Guangzhou. Trop. Geogr. 2009, 2, 123-128.

5. Li, S.; Mao, S. Exploring residential mobility in Chinese cities: An empirical analysis of Guangzhou. Urban Stud. 2017, 54, 3718-3737. [CrossRef]

6. Li, S.; Mao, S.; Du, H. Residential mobility and neighbourhood attachment in Guangzhou, China. Environ. Plan. A Econ. Space 2019, 51, 761-780. [CrossRef]

7. Sharp, G. Neighbourhood Attachment in Dynamic Perspective: Changing People and Changing Contexts; The Pennsylvania State University Press: University Park, PA, USA, 2013.

8. $\mathrm{Wu}, \mathrm{F}$. Residential relocation under market-oriented redevelopment: The process and outcomes in urban China. Geoforum 2004, 35, 453-470. [CrossRef]

9. Zhu, Y.; Breitung, W.; Li, S. The Changing Meaning of neighborhood Attachment in Chinese Commodity Housing Estates: Evidence from Guangzhou. Urban Stud. 2012, 49, 2439-2457. [CrossRef]

10. Li, S.-M.; Song, Y.-L. Redevelopment, Displacement, Housing Conditions, and Residential Satisfaction: A Study of Shanghai. Environ. Plan. A Econ. Space 2009, 41, 1090-1108. [CrossRef]

11. Song, Y.; Chiang, L.; Li, S. The place attachment of residents displaced by urban redevelopment projects in Shanghai. Issues Stud. 2012, 48, 43-73.

12. Zhang, C.; Lu, B. Residential satisfaction in traditional and redeveloped innercity neighborhood: A tale of two neighborhoods in Beijing. Travel Behav. Soc. 2016, 5, 23-36. [CrossRef]

13. Chen, J.; Hu, M.; Lin, Z. Does housing unaffordability crowd out elites in Chinese superstar cities? J. Hous. Econ. 2019, 45, 101571. [CrossRef]

14. Du, H.; Li, S. Is It Really Just a Rational Choice? The Contribution of Emotional Attachment to Temporary Migrants' Intention to Stay in the Host City in Guangzhou. China Rev. 2012, 12, 73-94.

15. Wu, F.; Logan, J. Do rural migrants 'float'in urban China? Neighbouring and neighborhood sentiment in Beijing. Urban Stud. 2016, 53, 2973-2990. [CrossRef]

16. Wang, F.; Wang, D. Changes in residential satisfaction after home relocation: A longitudinal study in Beijing, China. Urban Stud. 2020, 57, 583-601. [CrossRef]

17. Galster, G.C.; Hesser, G.W. Residential satisfaction composition a land contextual correlates. Environ. Behav. 1981, 13, 735-758. [CrossRef]

18. Djebuarni, R.; Al-Abed, A. Satisfaction level with neighbourhood in low income public housing in Yemen. Prop. Manag. 2000, 18, 230-242. [CrossRef]

19. Hadavi, S.; Kaplan, R.; Hunter, M.R. How does perception of nearby nature affect multiple aspects of neighborhood satisfaction and use patterns? Landsc. Res. 2018, 43, 360-379. [CrossRef]

20. Cao, X.; Wang, D. Environmental correlates of residential satisfaction: An exploration of mismatched neighborhood characteristics in the Twin Cities. Landsc. Urban. Plan. 2016, 150, 26-35. [CrossRef]

21. Theodori, G. Community attachment, satisfaction, and action. Community Dev. 2004, 35, 73-86. [CrossRef]

22. Hipp, J. What is the 'neighbourhood' in neighbourhood satisfaction? Comparing the effects of structural characteristics measured at the micro-neighbourhood and tract levels. Urban Stud. 2010, 47, 2517-2536. [CrossRef] 
23. Leslie, E.; Cerin, E. Are perceptions of the local environment related to neighborhood satisfaction and mental health in adults? Prev. Med. 2008, 47, 273-278. [CrossRef] [PubMed]

24. Amole, D. Residential satisfaction in students' housing. J. Environ. Psychol. 2009, 29, 76-85. [CrossRef]

25. Li, S.; Zhu, Y.S. Residential mobility within Guangzhou city, China, 1990-2010: Local residents versus migrants. Eurasian Geogr. Econ. 2014, 55, 313-332. [CrossRef]

26. Rossi, P. Why Families Move; MacMillan: New York, NY, USA, 1955.

27. Clark, W.A.V.; Ledwith, V. Mobility, Housing Stress, and Neighbourhood Contexts: Evidence from Los Angeles. Environ. Plan. A 2006, 38, 1077-1093. [CrossRef]

28. Clark, W.A.V.; Withers, S.D. Family migration and mobility sequences in the United States: Spatial mobility in the context of the life course. Demogr. Res. 2007, 17, 591-622. [CrossRef]

29. Tucker, C.; Marx, J.; Long, L. “Moving on": Residential mobility and children's school lives. Sociol. Educ. 1998, 71, 111-129. [CrossRef]

30. van Ham, M. Housing behaviour. In Handbook of Housing Studies; Sage: London, UK, 2012; pp. 47-65.

31. Bolan, M. The mobility experience and neighborhood attachment. Demography 1997, 34, 225-237. [CrossRef] [PubMed]

32. Temelová, J.; Slezáková, A. The changing environment and neighbourhood satisfaction in socialist high-rise panel housing estates: The time-comparative perceptions of elderly residents in Prague. Cities 2014, 37, 82-91. [CrossRef]

33. Brazil, N. Hispanic neighbourhood satisfaction in new and established metropolitan destinations. Urban Stud. 2019, 56, 2953-2976. [CrossRef]

34. Forrest, R.; Yip, N. Neighborhood and neighbouring in contemporary Guangzhou. J. Contemp. China 2007, 16, 47-64. [CrossRef]

35. Li, S.-M. Life Course and Residential Mobility in Beijing, China. Environ. Plan. A Econ. Space 2004, 36, 27-43. [CrossRef]

36. Ren, H.; Folmer, H. Determinants of residential satisfaction in urban China: A multi-group structural equation analysis. Urban. Stud. 2016, 54, 1407-1425. [CrossRef]

37. Zou, J.; Chen, Y.; Chen, J. The complex relationship between neighbourhood types and migrants' socio-economic integration: The case of urban China. Neth. J. Hous. Environ. Res. 2019, 35, 65-92. [CrossRef]

38. Wellman, B.; Leighton, B. Networks, Neighborhoods, and Communities Approaches to the Study of the Community Question. Urban Aff. Rev. 1979, 14, 363-390.

39. Liao, B.; Wong, D. Changing urban residential patterns of Chinese migrants: Shanghai, 2000-2010. Urban. Geogr. 2015, 36, 109-126. [CrossRef]

40. Luo, J.; Wei, Y.D. Population Distribution and Spatial Structure in Transitional Chinese Cities: A Study of Nanjing. Eurasian Geogr. Econ. 2006, 47, 585-603. [CrossRef]

41. Day, J. Effects of Involuntary Residential Relocation on Household Satisfaction in Shanghai, China. Urban. Policy Res. 2013, 31, 93-117. [CrossRef]

42. Li, L.; Li, S.M. Becoming homeowners: The emergence and use of online neighbourhood forums in transitional urban China. Habitat Int. 2013, 38, 232-239. [CrossRef]

43. Zhou, Y.; Logan, J.R. Growth on the Edge: The New Chinese Metropolis. In Urban China in Transition; Logan, J.R., Ed.; Blackwell: Malden, MA, USA, 2008; pp. 140-160.

44. Corrado, G.; Corrado, L.; Santoro, E. On the Individual and Social Determinants of Neighborhood Satisfaction and Attachment. Reg. Stud. 2013, 47, 544-562. [CrossRef]

45. Flaherty, J.; Brown, R.B. A Multilevel Systemic Model of Community Attachment: Assessing the Relative Importance of the Community and Individual Levels. Am. J. Sociol. 2010, 116, 503-542. [CrossRef]

46. Shen, J.; Wu, F. Moving to the Suburbs: Demand-Side Driving Forces of Suburban Growth in China. Environ. Plan. A Econ. Space 2013, 45, 1823-1844. [CrossRef]

47. Yip, N.M.; Leung, T.T.F.; Huang, R. Impact of Community on Personal Well-Being in Urban China. J. Soc. Serv. Res. 2013, 39, 675-689. [CrossRef]

48. Chen, J.; Wu, F. Housing and land financialization under the state ownership of land in China. Land Use Policy 2020, 104844. [CrossRef]

49. Shen, J. Stuck in the suburbs? Socio-spatial exclusion of migrants in Shanghai. Cities 2017, 60, 428-435. [CrossRef]

50. Zhu, Y.; Fu, Q. Deciphering the Civic Virtue of Communal Space Neighborhood Attachment, Social Capital, and Neighborhood Participation in Urban China. Environ. Behav. 2016. [CrossRef]

51. Bourdieu, P. The Forms of Capital. In Handbook of Theory and Research for the Sociology of Education; Richardson, J.G., Ed.; Greenwood Press: New York, NY, USA, 1986; pp. 241-258. 